\title{
OPTIMIZING THE ROLE OF INTEGRATED URBAN TRANSPORT FOR SUPPORTING TOURISM IN INDONESIA. CASE STUDY: SPORTING EVENT ASIAN GAMES 2018 JAKARTA
}

\author{
Purnama Anjasmara1, Nurul Urfani' ${ }^{2}$, Devi Marlita ${ }^{3}$ \\ 1. STMT Trisakti, 2. STMT Trisakti, 3. STMT Trisakti \\ $\triangle$ corresponding author: purnama.anjasmara@gmail.com ${ }^{1}$
}

\begin{abstract}
Transportation and tourism are two interrelated fields. From the past until now the purpose of people in traveling is growing, ranging from education, holidays, religious activities, health, business and so on. In order to facilitate, accelerate, streamline all human needs processes in such a journey absolutely need a means of transportation that is integrated with each other and sustainable. Given the beauty and richness of nature and culture owned by Indonesia, and through the momentum of ASIAN GAMES 2018 held in Jakarta-Palembang is a huge potential to attract foreign tourists to come to Indonesia that will bring in foreign exchange. The approach in this research is descriptive qualitative method which will be done in detail or in depth discussion through observation and interview, and spreading of questionnaires which in the process of sampling doing randomly to foreign tourists and with sample saturated to citizen of DKI Jakarta public transportation user. Regression analysis was used to analyze the data collected. The result shows that coefficient of transportation towards tourism is 0.55 There is a close relationship between transport and tourism which shown by value of $\mathrm{R}$ square is 0.78 and a coefficient of determination is $60.84 \%$.
\end{abstract}

Keywords: Urban Transport, Tourism Attractions, Sporting Event, Sustainable Tourism

\section{Introduction}

Transport has a close relationship to the growth of tourism. With the good transport facilities in a country it will increase the number of tourist visits in the country. The development of the tourism sector in the country is expected to drive the development of transportation in the country. Accessibility is the main function of the base behind the tourism transport. A country can be seen as developed country from how the transport system has been applied in that country, and how the airports of the country serves as a gateway traveler beginning to get into the region. Tourism emerged from Abraham Maslow's 
theory of motivation according to the theory of hierarchy of needs, "To reach the next requirement, basic needs must be met first". Based on this theory, every human being compelled to travel to meet their needs. Nowadays, travel has become a staple of human life.

In general, a person who are doing travel is motivated by tourist attraction which have by that country, such as state of nature, flora and fauna, the work of human, historical heritage, cultural and many others. Along with the times, a tourist attraction now not only limited by the things mentioned above, the current government is heavily organized events such as the national and international sporting events program. Indonesia with all its natural beauty and culture has great potential in terms of sports tourism which can be used as a tourist attraction (Astuti, 2015)

The tourism sector is one sector which can push a country's economic growth through foreign exchange earnings coming from this sector. Currently the tourism accounted for 12 billion US dollars and ranks fourth under the oil and gas, coal and palm oil (Statistics Ministry of Tourism). The rapid growth of tourism, especially as we know in 2018 Indonesia hosted the biggest sporting event in Asia which will be held in Jakarta and Palembang. From this event there will be many foreign tourists who will come to just watch, support the country's representatives to compete, and it is not likely they will be to travel other than this purpose, it is necessary to put an attention not only by government agencies, but also by other stakeholders such as the tourism industry, tourism industry associations, local communities and others, while nowadays government has developing many kind of infrastructures such as airport, terminal, toll road (highway), and so on. The tourist attraction's infrastructure development is also intended for developing the Indonesian tourism industry (Simarmata et al., 2017). With the sustainable and integrated transport system, known as Urban Transport, is expected to facilitate, accelerate, and to effectiveness of travelers to travel. 
Why urban transport? Because this time the problems of transport in Indonesia is particularly in Jakarta as one of the hosts of the event are not yet integrated between air transport, sea and land, and also the lack of quality of service and security of urban transportation. Provision of mass transportation is not in accordance with adequate infrastructure. Sustainable transport policy in Indonesia determined to be three parts. There is a public transport system, buses and trains orientation, with facilities, capacity, and a good quality of urban road network. Through the program NAMA SUTRI (Sustainability Urban Transport Program Indonesia), now there are several projects that lead to urban transport, such as the implementation of sustainable transport in the city: Facilities Integration of BRT, Palembang (2012) and LRT (2017), Walking Facilities, Bogor (2012), Parking Meter, Jakarta (2015), LRT, MRT, and Railink Jakarta (2017) (Source: Bappenas, 2016). Transportation derived from the Latin word "Transportare", which means the trans side or the other side, and portare means transporting or carrying. So the transportation means transporting or carrying (something) other fence or from one place to another Herry Gunawan (2014: 1). Transport can be defined as a business and activities of transporting or carrying goods and/or passengers from one place to another. Urban transport (Urban Transport) is a transportation system that emphasizes connectivity, efficiency, effectiveness, facilities, capacity, quality of city road network is good and transportation management that takes into account the user interaction services, transportation system that will provide a wide range of possibilities accessibility options that can minimize the negative impact of journey. (Prihartono, 2016). The term comes from the implementation of the tourism activity or tour that is a change of someone's residence, out of habitual residence - day temporary with an excuse anything except engage in activities that result in wage or salary. Someone who travel called travellers. Travelers are someone who travels to another country / elsewhere than from the State / place outside his residence with the main purpose of the visit in addition to the 
reasons not for doing activities that generate wage (The International Union of Office Travel Organization and the World Tourism Organization).

Tourism is a wide range of tourist activities and supported a variety of facilities and services provided by communities, businesses, governments, and local governments (Law No.10 of 2009). Tourism is an activity that utilizes the services of nature and environmental activities are typical, as the result of cultural, historical heritage, beautiful natural scenery and comfortable climate. (Indonesian President Instruction No. 19 of 1969). Tourist attraction is anything that has a uniqueness, beauty and value the form of diversity, a wealth of natural, cultural and man-made results of the target or destination of tourists visit. (Law No. 10 of 2009). These attractive properties include natural beauty, cultural attractions, and buildings of historical relics.

\section{Method}

This research aim to see the role of transport as a means to bolster the tourism activities in this regard in the framework of Asia's largest sports event, namely the Asian Games which will take place in Jakarta-Palembang in August the year 2018. The approach in this research is descriptive qualitative method which will do detailed in-depth discussion or through observation and interviews as well as the spread of saturated sample questionnaires to foreign tourists as well as service users public transportation in Jakarta that researchers can use as a sample. And it also comes with information on the can through a few journals, literature, the theory has existed at this time which has a connection with a theme that was made as well as statistical data that will be transformed into the form of a narrative about the development of the transport system in Jakarta and the number of tourists coming to Jakarta through air transport, which would further strengthen the theory to analyze about the role of transportation in the sporting event to support the Asian Games in Jakarta in 2018. 


\section{Discussion}

To strengthen the analysis with the existing theory, this study also used a simple linear regression analysis previously performed distributing questionnaires to 157 respondents that the majority of respondents still a student and most nationals of Indonesia with 149 people and eight foreigners. Based on calculations by simple linear regression analysis, known value of $a$ is at 16 and the value of $b$ is 0:55 to obtain a simple linear regression equation is $\mathrm{Y}=16+0: 55 \mathrm{X}$. Correlation coefficient or $\mathrm{b}$ at $0: 55$, which means that the development of the transport system will be followed by increase in the number of tourism at 0:55 and then coupled with a constant that is equal to 16 .

To be able to see the relationship between the independent variable $(\mathrm{X})$, with the dependent variable (Y), it is necessary to do the analysis of the correlation coefficient between variables of the study. With the result that the correlation coefficient between variable $\mathrm{X}$ with variable $\mathrm{Y}$ is at 0.78 which shows that there is a close relationship because it is located at the interval 0.70.89 , and to determine the contribution of transport to tourism can be calculated using the coefficient of determination with the results of the R-square is $60.84 \%$, This means there is a positive relationship between transport by tourism amounted to $60.84 \%$, while the remaining $100 \%-60.84 \%=39.16 \%$ is another factor. Other variables that can affect the number of tourists visiting Indonesia, especially Jakarta, like government's role in efforts to promote the attraction of Indonesia especially in Jakarta that Year 2018 will host the biggest sporting event organizing in Asia, as well as the facilities that are available at the tourism itself.

From processing questionnaires that are still very low level of public confidence in the role of transportation in Jakarta to support tourism. Other results showed that the transportation system and the development of transportation in the capital city is still not maximal, like transport infrastructure in Jakarta not affordable for the persons with disabilities, in 
which people with disabilities also have the same rights in terms of transportation services, and also transportation system in Jakarta not integrated yet so as to get a tourist destination in Jakarta is relatively difficult to reach. Keep in mind that the real function of transportation is for making easy, accelerate the mobility of its citizens and tourists, and meet the satisfaction with service quality. (Saribanon et al., 2016) Through a program run by the Ministry of Tourism and Creative Economy, tourism development strategy in Indonesia is divided through three entrances called 3 greater, namely Greater Bali, Greater Jakarta and Greater Batam. As one of the region into the national tourism development strategy, Jakarta is expected to be the entrance for foreign tourists beginning through Soekarno-Hatta airport that serves international flights which is also ranked on the top 10 busiest airport in the world. (Martono \& Marina, 2009). From Table 1, show that the number of tourist arrivals through Soekarno-Hatta International Airport in the last 5 years has increased the average percentage $22.25 \%$ per year. this shows that Jakarta has the potential to bring great traveler.

\begin{tabular}{|l|c|c|c|c|c|}
\hline \multicolumn{1}{|c|}{$\begin{array}{c}\text { PORT OF } \\
\text { ENTRY }\end{array}$} & $\mathbf{2 0 1 3}$ & $\mathbf{2 0 1 4}$ & $\mathbf{2 0 1 5}$ & $\mathbf{2 0 1 6}$ & $\mathbf{2 0 1 7}$ \\
\hline $\begin{array}{l}\text { SOEKARNO - } \\
\text { HATTA }\end{array}$ & $2,240,502$ & $2,246,437$ & $2,455,279$ & $2,603,165$ & $1,836,105^{*}$ \\
\hline
\end{tabular}

Table 1.

The number of foreign tourist comes Soekarno-Hatta 2013-2017 (*temporary data as of date August $31^{\text {st }}$ 2017)

Source : stats arrival statistic Ministry of Tourism

Air transport industry and tourism are interrelated each other. Tourism depends on air transportation to bring tourist, while the air transportation industry depends on tourism to increase demand for its services. The growth in tourism industry directly affected onto the growth of air transportation (Ricardianto et al., 2017). By looking at the potential of Jakarta provincial government is currently being intensively build an integrated transport system, where the transportation system starting from the airport as a gateway of 
tourists who came to Jakarta. In 2 years, the role of air transport to tourism in Indonesia has reached more than $80 \%$, with an increase from previous years, because of the travel time is the fastest than land or sea transport.(Darunanto et al., 2016) There are several types of land transportation as a link to and from airport, such as DAMRI, JA Connextion, Taxi, Car Rent, Online transportation and even there are hotels that already give a shuttle bus facility.

Henceforth there will be train to the airport, so more and more variations of types of transportation modes that can be selected for the tourists who will visit Jakarta. Transportation in the city for its own such as the availability of various types of public transportation with a total number of 45.902 vehicles (Source: Jakarta Transportation Statistics 2015/2016). In addition there are Transjakarta bus, rail commuter line JABODETABEK and so forth, and there are currently two mega-projects the government is doing, namely Jakarta MRT and LRT.

To support the Asian Games event 2018 will be held in Jakarta, the government still has to make an improvement of the transportation system in Jakarta. The high mobility of Jakarta citizens are not support by the availability of public transport that is safe and comfortable. High crime rate that occurred on public transport, and still not environmentally friendly, and especially transportation infrastructure in Jakarta is not affordable for people with special needs, such as persons with disabilities and the elderly, of these factors, Jakarta citizens prefer to use of private cars, so that the growth of both cars and motorcycle continues to rise and is not offset by the growth of the road. 


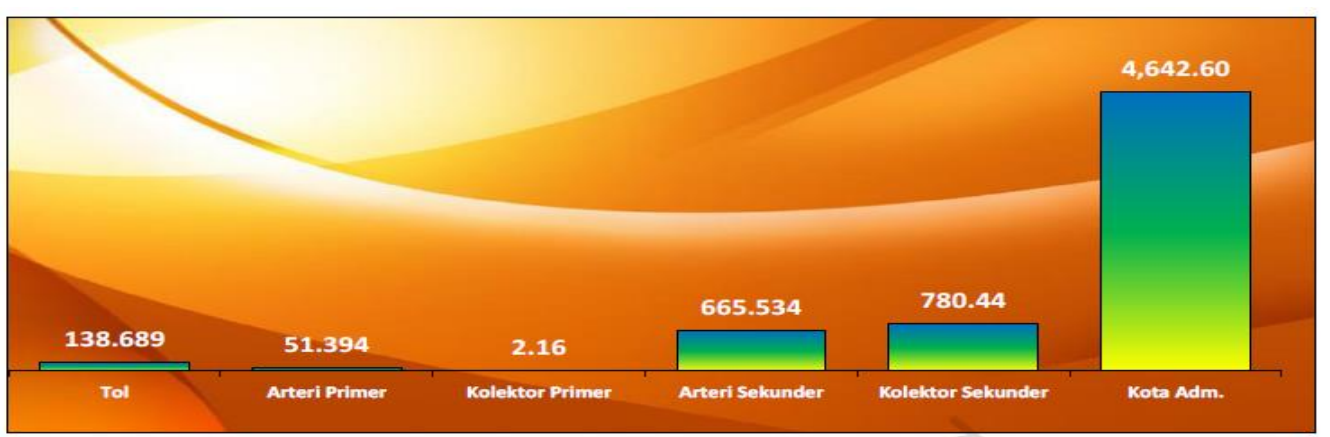

Figure 1. The length of the road the year 2016 in Kms. (Sources: Transportation Statistics DKI Jakarta 2015/2016)

Figure 1 shows the length of the road the year 2016, if specified according to its kind, is the longest road in the form of the city administration along the 4,642.6 km; followed along the provincial road $1.445 .97 \mathrm{~km}$ consists of a secondary arterial and secondary collectors each along $665.53 \mathrm{~km}$ and 780.44 $\mathrm{km}$; While state road along $53.55 \mathrm{~km}$ consists of a primary arterial and collector each primer along $51.39 \mathrm{~km}$, and $2.16 \mathrm{~km}$, next motorway last all $138.68 \mathrm{~km}$. While the growth of motorcycle during the last five years it reaches 5.35 percent per annum. If the specified according to the type of vehicle, passenger car experienced the highest growth i.e. of 6.48 percent per year with a total of 3 525925 units in 2016. After that the motorcycle, which experienced growth of 5.30 percent per year with a total of 13310672 units by the year 2016. (Source: Jakarta 2015/2016 Transportation Statistics).

Infrastructure which safe and comfortable transportation in Jakarta already should be the main focus by the Government of DKI Jakarta, especially to support the 2018 Asian Games be held in Jakarta. To overcome all these problems, the Government is currently trying to develop a system of mass transport through the decision of the Governor of DKI Jakarta No. 84 Year 2004 concerning the determination of Macro Transport Patterns in DKI Jakarta Province Chapter III article 3 point $b$ and e, "popularized the Mass public transport system and adds the primary Chain, Subway and Busway," which set out the security, convenience, punctuality and surely integrated and 
environmentally friendly. In accordance with the concept of Urban Transport, where the focus is the transportation system in the form of Buss Rapid Transit (BRT), Mass Rapid Transit (MRT) and Light Rapid Transit (LRT). For BRT in itself already released by the TransJakarta currently there are 13 corridor service that have a special path although until recently the line was still not completely sterile. To the MRT and LRT himself still in the stages of workmanship and for the MRT was expected to be completed before 2018 Asian Games Jakarta began. With a maximum of one set of train consists of six trains, this mode of transportation is estimated to be able to serve passengers to 173,000 people per day. Expected with the MRT can reduce congestion in Jakarta, and add to the attraction of tourists to conduct tours in Jakarta.

In relation to the 2018 Asian Games in Jakarta, the government has programmed with a similar type of tourism that is through competition in sports. Has a lot of sporting events that have taken place or are still in the form of program to be executed in 2018, both held in Jakarta and other cities in Indonesia. Sporting events such as the Asian Triathon Championship 2017 in Palembang, The 36th International Junior Tennis Championship 2017 in Surabaya, the Tour de Lombok Mandalika 2017 in Lombok, Yogyakarta Marathon 2017 in Yogyakarta, Jakarta Marathon, the Tour de Singkarak, Tour de Bintan and which will take place on 6 to 8 November included Tour de Central Celebes. Sporting an international event can be used as tourism potential, because the majority of participants came from abroad, Through Jakarta Marathon, government can promote Jakarta as a tourist destination. Because it is a lot of tourist attraction in Jakarta, such as museums, theme park like DUFAN, Taman Impian Jaya Ancol, educational tours such as Ragunan Zoo, Taman Mini Indonesia Indah in which there are also museums, traditional house of 33 provinces in Indonesia, and other entertainment. But the Ancol area where tourism is the most visited by tourists with the number of 16 million visits in 2015, compared with other tourist attractions. Besides the 
Jakarta administration was continuing to develop greening by building parks in the town center which can be an additional attraction for tourists. The area of the park in Jakarta increased from 27.349.258.00 $\mathrm{m}^{2}$ in 2013 to 27.488.095.21 $\mathrm{m}^{2}$ in 2014. The largest park area located in South Jakarta in the amount of 6.291.111.48 $\mathrm{m}^{2}$. Meanwhile, the smallest park is located in the thousand Islands area of $44.995 .00 \mathrm{~m}^{2}$. (Source: BPS, Jakarta in Figures 2016)

From those kinds of sports events, has proved to bring many tourists, especially the Asian Games event that was already sure the participants are foreign nationals from the country bringing more supporters for their support at the event. In addition to the tourist attraction in Jakarta also has a cluster of Islands-which is in the Bay of Jakarta is the Thousand Islands. Thousand islands currently visited by many foreign tourists and citizens of Jakarta alone. The island is quite popular among the tourists is Tidung Island, Pari Island, Pramuka Island, Genteng Kecil Island, Umang Island, and H Island which is able to attract the attention of foreign tourists. These islands have their appeal. All tourist attraction owned by Jakarta, they must be in power use well with regard to accessibility, and equipped with facilities that support such as ATM, public restroom, or even can be packed by adding cultural festivals in tourism is to increase the number of tourists visiting.

If power attractiveness of tourist attraction that has been packaged well through third aspect, will attract foreign tourists where its main target is the athletes involved in the Asian Games and supporters, if when they aren't competing, they can visit tourist objects Jakarta mentioned above. With the arrival of the foreign travelers who would be more acceptable. The tourism sector is one sector which is the mainstay in foreign exchange earnings needed for national development as well as Jakarta itself. Foreign exchange earnings from the tourism sector in 2015 is ranked 4th with a number of foreign exchange earnings amounted to 12.22 Billion USD (Source: Statistics Ministry of Tourism). With the advancement of tourism in the region, will bring 
creativities societies around the sights. So that the economy around these attractions will move and if this is done in a variety of areas will certainly help improve the distribution of economic growth in Indonesia

Amid all the positive things the tourism sector, there is the negative side. With the foreign tourists who come from different countries, of course, they will also bring the habit, cultures, from the countries where they come to Jakarta. Habits or cultures are not always such a good thing, for it is in the development of tourism in Indonesia should remain guided by the philosophy of Pancasila as the nation which serve as a filter to foreign cultures that do not fit with the personality of the Indonesian nation.

\section{Conclusion}

There is a close relationship between transport and tourism with $\mathrm{R}$ square value of 0.78 and a coefficient of determination of $60.84 \%$. By taking the momentum of 2018 Asian Games in Jakarta, all the existing tourism potential in Jakarta must be packaged properly and synergy by all stakeholders both communities, central and local government organizations and other tourism parties through three aspects: tourist attraction, accessibility and facilities that are attractive and can provide ease and convenience for travelers who are targeted for the athletes and supporters who came to Jakarta. However, the results of the processing of the questionnaire consisting of several foreigners and citizen, respondents still complain of Jakarta's transportation system has not been well integrated, so as to achieve a tourism destination relatively difficult to reach, and yet kindly on the environment as well as to persons with disabilities. There is still less than a year for all stakeholders to make improvements related to transportation's infrastructure \& facilities and tourism in Jakarta, so as to support the event Asian Games as well as foster the tourism sector. 


\section{References}

Ardhia, W. (2013). Role of Low-Cost Airlines in Adisutjipto Airport Yogyakarta for Increasing Number of Domestic Tourist. 145-164.

Analisis Kunjungan Wisatawan Mancanegara pada Greater Jakarta. (2015, Januari-December). Jakarta: Ministry Of Tourism

Astuti, M. T. (2015). Sport Tourism to Increase Tourist Arrival in Indonesia. $31-40$.

Budiartha, N. (2011). The Role of Transportation in Tourism. 195-204.

Dewi, I. J. (2011). Responsible Tourism Marketing. Jakarta: Ministry of Tourism.

Darunanto, D. (2016) Layanan Terhadap Kepuasan Pelanggan Pt . Dms Tour And Travel, 201-219.

Hasan, A. (2015). Tourism Marketing. Yogyakarta: PT. BUKU SERU.

Indonesia Constitution of Tourism No. 10 (2009).

Keputusan Gubernur DKI Jakarta No. 84 (2004). Penetapan Pola Transportasi Makro di Provinsi DKI Jakarta. Jakarta.

Martono, K., \& Marina, S. (2016) Domestic Air Transport Regulations in Indonesia, 1-19.

Muljadi, D. A., \& Warman, H. A. (2014). Kepariwisataan Dan Perjalanan. Depok: PT. Rajagrafindo Persada.

Policy, D. A. (2013-2017). Stats of Arrivals by Port of Etntry. Jakarta: Ministry Of Tourism.

Ricardianto, P., Djajaputra, G., Martono. (2017). Air Transport and Tourism in Indonesia, 1-19.

Saribanon, E, Sitanggang, R.(2016). The Satisfaction Of Transportation's Customers to Enhance Loyalty, 317-326.

Sasongko, T. S. (2014). Kompleksitas Hubungan Antara Pariwisata, Politik, dan Manajemen Sektor Public. 87-96.

Simarmata, J., \& Keke, Y. (2017). The Influence of Travel Agent, Infrastructure and Accommodation on Tourist Satisfaction, 281-283.

\section{Website:}

https://batampos.co.id/2017/09/27/ini-dasar-penetapan-100-event-berskalainternasional-oleh-kemenpar/ (accessed on October $24^{\text {th }} 2017$ )

https://ads2.kompas.com/layer/kemenpar/detail/3970 (accessed on October $24^{\text {th }}$ 2017)

http://www.isdb-am41.org/wp-content/uploads/2016/06/5-BAPPENAS-

Sustainable-Transport-Policy_IDB_150516-1.pdf (downloaded on

October $25^{\text {th }} 2017$ )

https://people.hofstra.edu/geotrans/eng/ch7en/appl7en/ch7a3en.html

(accessed on November $2^{\text {nd }} 2017$ )

https://unhabitat.org/wpcontent/uploads/2013/06/GRHS.2013.Case .Study .Jak

arta.Indonesia.pdf (downloaded on October $27^{\text {th }} 2017$ ) 
http://www.sutp.org/en/projects/indonesia-sustainable-urban-transportimprovement-project.html (accessed on October $25^{\text {th }}$ 2017)

https://www.openaip.net/node/154393/node_last_approved (accessed on November $8^{\text {th }} 2017$ )

http://transferproject.org/wp-content/uploads/2014/11/Overview_IND_SUTRINAMA.pdf (downloaded on October 26 $6^{\text {th }} 2017$ )

https://jakarta.bps.go.id/index.php/publikasi/203 (downloaded on November $4^{\text {th }}$ 2017)

https://jakarta.bps.go.id/index.php/publikasi/182 (downloaded on November $4^{\text {th }}$ 2017)

http://www.kemenpar.go.id/asp/detil.asp?c=16\&id=2307 (downloaded on October $29^{\text {th }} 2017$ ) 